Studia Judaica 24 (2021), nr 1 (47), s. 123-151

doi:10.4467/24500100STJ.21.005.14607

Adam Stepnowski iD https://orcid.org/0000-0002-1427-530X

\title{
Genderowy wymiar jidyszowej literatury masowej w twórczości Szomera
}

\author{
THE GENDER DIMENSION OF YIDDISH POPULAR LITERATURE \\ IN SHOMER'S WRITINGS
}

\begin{abstract}
The article explores a model of construing gender in Yiddish shund (trash) literature. The author focuses on three aspects-womanhood, manhood, and relationships-comparing both cultural ideals and historical reality of Ashkenazic Jewry at the end of the nineteenth century with the gender roles constructed in the novels. The focus is placed on the stories of Nokhem Meir Shaykevitch (Shomer), the most popular shund writer of that time. The author of the article emphasizes the gender ideals in Shomer's novels and investigates possible ideological inspirations that led the writer to bring the ideals to a textual level.
\end{abstract}

Keywords: popular literature, gender studies, Yiddish literature, Shomer.

Słowa kluczowe: literatura popularna, gender studies, literatura jidysz, Szomer.

\section{Wstęp}

Modelowe kobiece i męskie role społeczne wśród Żydów, różniące się od tych spotykanych w kulturach chrześcijańskich, były wielokrotnie przedmiotem badań literaturoznawczych. Piśmiennictwo jidyszowe z powodu swojego „kobiecego charakteru” (mame-loszn, język związany ze sferą domową, zestawiany często z patrylinearnym hebrajskim) było również ważnym obszarem badań feministycznych ${ }^{1}$. Opierając się na krytyce

${ }^{1}$ Anita Norich, Jewish Literatures and Feminist Criticism: An Introduction to Gender and Text, [w:] Gender and Text in Modern Hebrew and Yiddish Literature, red. Naomi B. Sokoloff, Anne Lapidus Lerner, Anita Norich, New York 1992, s. 1-15. Ważną publikacją na 
feministycznej i metodach związanych ze studiami genderowymi, badano takie grupy tekstów, jak: tchines $^{2}$, Cene u-rene ${ }^{3}$, egodokumenty ${ }^{4}$, oraz utwory należące do kanonu literatury jidysz ${ }^{5}$. Grupą tekstów słabo zbadaną do tej pory jest jidyszowa literatura masowa. Choć jej stereotypowy związek z kobiecością był wskazywany już na przełomie XIX i XX w. ${ }^{6}$, a we współczesnych badaniach sygnalizowano jej wpływ na czytelniczki ${ }^{7}$, to same teksty jidyszowej kultury popularnej wciąż wymagają wnikliwej analizy. W niniejszym artykule postaram się potwierdzić tezę Gennady'ego Estraikha, że literatura masowa jest równie bogatym źródłem do badań nad genderowym wymiarem jidyszowej twórczości, jak wyżej wymienione, lepiej zbadane grupy tekstów ${ }^{8}$. Głównym celem analizy będzie zaś prześledzenie procesu kształtowania nowych modeli męskości i kobiecości na wybranych przykładach.

Określenie „literatura masowa” wskazuje, szczególnie w kontekście jidysz, na duży i amorficzny zakres tekstów, dlatego na potrzeby tego artykułu należy dokonać zawężenia materiału do analizy. Chciałbym skupić się na tekstach cyrkulujących w Europie Wschodniej przed 1914 r., kiedy na tamtym obszarze można było zaobserwować dużą dynamikę zmian w społeczności żydowskiej dotyczącą również ról genderowych. Głównym materiałem źródłowym będą książki jednego z najpoczytniejszych pisarzy w tamtym okresie - Nochema Meira Szajkewicza (tworzącego również pod pseudonimem Szomer) ${ }^{9}$.

tym polu jest również książka Naomi Seidman. Zob. Naomi Seidman, A Marriage Made in Heaven: The Sexual Politics of Hebrew and Yiddish, Berkeley 1997.

${ }^{2}$ Chava Weissler, Voices of the Matriarchs: Listening to the Prayers of Early Modern Jewish Women, Boston 1998.

3 Joanna Lisek, Kol isze - głos kobiet w poezji jidysz (od XVI w. do 1939 r.), Sejny 2018, s. $65-69$.

${ }^{4}$ Należały do nich pamiętniki kobiet. Przykładem może być twórczość pamiętnikarska Glikl z Hameln. Zob. Glikl: Memoirs 1691-1719, oprac. i wstęp Chava Turniansky, tłum. Sara Friedman, Waltham 2019.

${ }^{5}$ Zob. Daniel Boyarin, Unheroic Conduct: The Rise of Heterosexuality and the Invention of the Jewish Man, London 1997, oraz Queer Theory and the Jewish Question, red. Daniel Boyarin, Daniel Itzkovitz, Ann Pellegrini, New York 2003.

${ }^{6}$ Zob. Szmuel Niger, Di jidisze literatur un di lezerin (1913), [w:] tenże, Bleter geszichte fun der jidiszer literatur, Nju Jork 1959.

${ }^{7}$ Iris Parush, Reading Jewish Women: Marginality and Modernization in Nineteenth-Century Eastern European Jewish Society, tłum. Saadya Sternberg, Waltham 2004.

${ }^{8}$ Gennady Estraikh, The Best-Selling Shomer and His Fear of Emancipated Women, [w:] Women, Men and Books: Issues of Gender in Yiddish Discourse, red. Gennady Estraikh, Mikhail Krutikov, Cambridge 2019.

${ }^{9}$ Szomer, właśc. Nochem Meir Szajkewicz (1849-1905). Urodzony w Nieświeżu, żydowski prozaik, poeta i dramaturg. Uznawany za jednego z najpopularniejszych twórców 
W artykule chciałbym ograniczyć się geograficznie do terenów Europy Wschodniej z dwóch powodów. Po pierwsze, większość twórczości Szomera była drukowana w Wilnie. Dystrybucja jego książek ograniczała się zatem początkowo głównie do Europy Wschodniej, gdzie znajdowały one rzesze odbiorców i odbiorczyń czytających w jidysz. Po drugie, transformacja genderowych ról społecznych w Europie Zachodniej zachodziła wcześniej ${ }^{10}$. Procesy emancypacyjne, akulturacja i zmiana ideału ról kobiecych i męskich to kwestia lat wcześniejszych niż druga połowa XIX w. Już wcześniej wytworzyła się tam żydowska klasa średnia, w której kobietom przypadło zajmowanie się domem, sferą religijną, filantropią i działaniem w organizacjach społecznych, podczas gdy mężczyzna zarabiał na dom. Wydaje się, że specyficznie żydowski wariant literatury masowej nie odegrał w tym przypadku dużej roli. Dynamika zmian pod tym względem w Europie Wschodniej przybrała inną trajektorię niż na Zachodzie. Pod wpływem haskali oraz zmian ekonomicznych i społecznych dopiero druga połowa XIX w. wiązała się tutaj z renegocjacją ról genderowych ${ }^{11}$. W tym samym czasie wśród jidyszowych odbiorców popularność zyskiwały krótkie książki o sensacyjnej lub romansowej tematyce, kategoryzowane później przez krytyków literackich jako szund (jid. 'tandeta', 'szmira') ${ }^{12}$. Pod koniec XIX w. pisarzem, który osiągnął największy sukces na tym polu, nadając ton całemu rodzajowi tego typu twórczości, był Szomer. Ze względu na popularność i wysokie nakłady książek tego autora to właśnie analiza jego dzieł będzie główną osią tego artykułu. Na przykładzie wybranych powieści prześledzę wątki związane z kreowaniem genderowego ideału

nowoczesnej literatury jidysz we wczesnym jej okresie. Rozpoczynał działalność literacką od publikowania po hebrajsku, następnie pod wpływem tworzącego się wówczas żydowskiego teatru postanowił spróbować swoich sił jako dramaturg. Największą sławę przyniosły mu jednak książki jidyszowe odpowiadające gustom odbiorców rozsianych po wschodnioeuropejskich sztetlach. Takie powieści jak Der blutiger adje, Der katorżnik czy Der frumer merder doczekały się nakładów sięgających kilkudziesięciu tysięcy egzemplarzy i wielu dodruków. Jego twórczość była krytykowana za zbyt zgermanizowany język, schematyczność i psucie rynku wydawniczego. W szczycie popularności, pod koniec lat osiemdziesiątych XIX w., przeniósł się do Ameryki, gdzie kontynuował pracę twórczą aż do swojej śmierci w 1905 r.

${ }^{10}$ ChaeRan Freeze, Paula Hyman, Introduction: Historiographical Survey, [w:] Jewish Women in Eastern Europe, red. ChaeRan Freeze, Paula Hyman, Antony Polonsky, OxfordPortland 2005, s. 13. Jak wyjaśniają autorki, miało to związek przede wszystkim z wcześniejszą emancypacją Żydów, większą integracją ekonomiczną oraz wysokim poziomem akulturacji.

${ }_{11}$ Paula Hyman, Gender and Assimilation in Modern Jewish History: The Roles and Representation of Women, Seattle-London 1995, s. 52.

${ }^{12}$ Więcej o zjawisku szundu zob. Chone Shmeruk, Le-toldot safrut ha-szund be-jidisz, „Tarbic” 52 (1983), s. 325-350. 
kobiety, mężczyzny oraz relacji między nimi w kontekście wyżej wymienionych zmian społecznych. Interpretację uzupełnię o wątki pojawiające się w innych opowieściach szundowych, jednak głównym materiałem źródłowym będą najpopularniejsze, wysokonakładowe książki Szomera: Halb mensz halb affe, oder, wu zucht men dem emes? [Półczłowiek, półmałpa, albo gdzie szuka się prawdy?] ${ }^{13}$, Gwald wu iz majn bord! [Ratunku! Gdzie moja broda?!] ${ }^{14}$, A sznel in noz [Prztyczek w nos] ${ }^{15}$ oraz Der katorżnik [Katorżnik] ${ }^{16}$. W każdej z nich pojawiają się różne wzorce kobiecości i męskości oraz kontrastujące modele rodzinnych i romantycznych relacji damsko-męskich. Ważnym kontekstem w obrębie tych tekstów jest również proces przypisywania poszczególnych cech nowym ideałom kobiecości i męskości, a więc formowanie nowych wzorców genderowych. Analiza tych utworów pozwoli pokazać, jakie treści ideologiczne były przekazywane jidyszowym czytelniczkom (i czytelnikom) w tamtym okresie ${ }^{17}$. Obserwacje zostaną podzielone na trzy grupy: kobiecość („,Od »kramarki-kozaka« do anioła w domu”), męskość („Od »jedwabnego Żyda« do businessmana”) oraz relacje („Od swatów do miłości romantycznej”).

Proponowane podtytuły porządkują kierunek zmian, na poziomie bardziej szczegółowym postaram się niuansować obraz konstruowania tych ideałów, ponieważ pozostawały one jedynie wzorcem służącym osiągnięciu konkretnego celu retorycznego na poziomie tekstualnym.

\section{Nowy model rozrywki i „nowa czytelniczka”}

Ostatnie dziesięciolecia XIX w. przyniosły dynamiczny rozwój wydawniczy druków jidyszowych oraz ukształtowanie się nowych typów czytelników i czytelniczek. Dla zobrazowania tego procesu przywołuje się dość często stereotypowy obraz rodziny, w której matka czyta Cene u-rene, a córka $\mathrm{z}$ wypiekami na twarzy zaczytuje się w opowieści Szomera ${ }^{18}$. Ten obraz

${ }^{13}$ Nochem Meir Szajkewicz (Szomer), Halb mensz halb affe, oder, wu zucht men dem emes, Wilne 1888.

${ }^{14}$ Nochem Meir Szajkewicz (Szomer), Gwald wu iz majn bord! Eyn roman, Warsze 1930.

${ }_{15}$ Nochem Meir Szajkewicz (Szomer), A sznel in noz, Wilne 1896.

${ }^{16}$ Nochem Meir Szajkewicz (Szomer), Der katorżnik, Wilne 1888.

${ }^{17}$ Pomimo że szund uchodził za literaturę wyłącznie kobiecą, powszechne było rodzinne czytanie tych książek. Takie obrazy pojawiają się na przykład we wspomnieniach Dory Szulner. Zob. Dora Szulner, Derinerungen wegn N. M. Szajkewicz (Szomer), [w:] taż, Gesztalten un derinerungen, Szikago 1956, s. 24-27.

${ }_{18}$ Niger, Di jidisze literatur... 
wymaga zniuansowania, jednak dobrze pokazuje, jak dynamicznie zachodziły zmiany i jak czytelnictwo książek religijnych (oraz dawnej literatury jidysz) traciło swój prymat na rzecz spędzania czasu ze świecką, nowoczesną literaturą popularną ${ }^{19}$. Literatura ta, jak i ogólnie piśmiennictwo jidyszowe uchodziły wciąż za domenę czytelniczek, lecz z egodokumentów można wywnioskować, że również mężczyźni byli często odbiorcami tego typu książek $^{20}$.

Szomer jest uznawany za najbardziej rozpoznawalnego pisarza jidyszowej literatury popularnej, a w badaniach nad szundem pojawia się jako prekursor tego rodzaju piśmiennictwa. Jego utwory są prezentowane jako wzór dla innych pisarzy (i naśladowców). Nie był on jednak pierwszym autorem jidyszowej literatury popularnej. Jego czytelnicy i czytelniczki to często osoby, które wcześniej czytały książki na przykład Ajzyka Meira Dika $^{21}$, tworzącego haskalowe powieści w mame-loszn. W czasach debiutu Szomera stosunkowo popularni byli też inni pisarze. Książki Mordechaja Spektora $^{22}$ czy Jankewa Dinezona ${ }^{23}$ także rozchodziły się w kilku- lub

${ }^{19}$ Parush, Reading..., s. 134-142.

${ }^{20}$ Szulner, Derinerungen...

${ }^{21}$ Ajzyk Meir Dik (1807/14?-1893) - pierwszy profesjonalny, bestsellerowy autor piszący prozę jidyszową. Urodzony w Wilnie, odebrał tradycyjną edukację, jednak nauczył się również niemieckiego, polskiego i rosyjskiego. W latach trzydziestych XIX w. zaangażował się w ruch haskalowy. Zdecydował się na pisanie w jidysz, ponieważ uważał, że język ten jest dobrym narzędziem do oświecenia mas żydowskich. Większość jego jidyszowych powieści powstała między rokiem 1860 a 1875 . W 1864 r. podpisał kontrakt jako autor powieści w wileńskim wydawnictwie braci Romm.

${ }^{22}$ Mordechaj (Mordche) Spektor (1858-1925) - jidyszowy pisarz i redaktor. Urodzony w Humaniu na Ukrainie, po odebraniu tradycyjnej edukacji, mając dziewiętnaście lat, zdecydował się na przeprowadzkę do Odessy i zaangażowanie w tamtejsze środowisko literackie. Na tle innych pisarzy tamtego okresu wyróżnia go to, że od początku pisał w jidysz, nie debiutując po hebrajsku lub rosyjsku. W latach osiemdziesiątych zamieszkał w Sankt Petersburgu, gdzie również rozpoczął karierę pisarza. Początkowo publikował osobne książki, następnie wysyłał swoje teksty również do tytułów prasowych i antologii. W 1920 r. zaangażował się w działania Kultur-lige w Odessie, a po umocnieniu się władzy radzieckiej na tych terenach wyemigrował do Stanów Zjednoczonych.

${ }^{23}$ Jankew Dinezon (1856?-1919) - jidyszowy pisarz i redaktor. Urodzony w okolicach Kowna, studiował w jesziwie do szesnastego roku życia, jednak już we wczesnym wieku nastoletnim rozpoczął pierwsze próby literackie. Po zapoznaniu się w Wilnie z Dwojrą Romm, szefową wileńskiego wydawnictwa, zaczął pisać powieści na zamówienie. W 1877 r. opublikował Der szwarcer junger-manczik [Czarny młodzieniaszek], który rozszedł się w nakładzie 10 tys. egzemplarzy i stał się pierwszym jidyszowym bestsellerem. Zniechęcony ostateczną jakością książki i porównaniami do Szomera, zawiesił karierę literacką do lat dziewięćdziesiątych. Wówczas rozpoczął również publikowanie książek dla dzieci, pamiętników i tłumaczeń. Wysyłał swoje artykuły do wszystkich znaczących jidyszowych dzienników. Po śmierci w 1919 r. został pochowany na cmentarzu w jednym grobowcu z Perecem, swoim literackim mentorem i przyjacielem. 
kilkunastotysięcznych nakładach, a ich autorzy cieszyli się wówczas równie dużą popularnością. Oprócz tego na scenie literackiej pojawiło się wielu innych pisarzy określanych jako szundowi, którzy tworzyli książki podobne to wydawnictw Szomera.

Co więc wpłynęło na to, że ostatecznie to szomeryzm stał się synonimem szundu, a dzieła Szajkewicza jego wyznacznikiem gatunkowym? Dużą rolę odegrał tutaj przebieg kariery autora i oparcie jej sukcesu na dwóch czynnikach: dostosowywaniu się Szomera do gustów czytelniczych oraz zdolności do tworzenia wielu książek, jedna po drugiej, na zamówienie. Początkowo, inspirowany wydawnictwami i sukcesem Dika, był autorem dłuższych powieści. W latach osiemdziesiątych i dziewięćdziesiątych, współpracując z wileńskimi wydawnictwami, zaczął skracać swoje teksty, pisząc coraz częściej 32-stronicowe opowieści. Umożliwiło mu to pisanie większej liczby książek rocznie, co przyniosło zarówno sukces finansowy (Szomer mógł utrzymywać się tylko z pisania, co wśród jidyszowych twórców w tamtym czasie było niespotykaną rzadkością), jak i rozpoznawalność we wszystkich jidyszowych ośrodkach. Następną innowacją wprowadzoną przez Szajkewicza, która miała wpływ na popularność jego publikacji, było odejście od typowej dla literatury haskali tendencji do edukowania odbiorców i odbiorczyń. Szomer, pomimo deklarowania dydaktycznego i moralizatorskiego charakteru swoich opowieści, wyraźnie stawiał na treści rozrywkowe i sensacyjne, opierające się na częstych zwrotach akcji i zaskakujących wydarzeniach.

Bibliografia jidyszowych książek Szomera liczy kilkaset utworów, jeśli uwzględnimy tylko samą prozę ${ }^{24}$. Ilość materiału oraz jego popularność wśród ówczesnych czytelników i czytelniczek sprawia, że jest to twórczość warta pogłębionych badań. Analizę zagadnień genderowych ułatwiają przy tym cechy charakterystyczne twórczości Szomera. Autor wielokrotnie w swoich powieściach i opowieściach wyraźnie dzielił bohaterów na dobrych i złych, często zestawiając modele postaci na zasadzie kontrastu. Korzystając z tego rodzaju ekspozycji, na przykładzie par bohaterów i bohaterek, przedstawię główne zagadnienia oraz tendencje w opisywaniu kobiet, mężczyzn i relacji między nimi.

${ }^{24}$ Pisał także poezję i dramaty - również po hebrajsku. 


\section{(Post)maskile i upadek sztetla}

Przed przejściem do analizy warto uporządkować realia historyczne związane z rolami genderowymi w społeczności żydowskiej oraz streścić, w jaki sposób tematyka ta pojawiała się w literaturze jidysz tamtego okresu.

Tradycyjne aszkenazyjskie społeczeństwo przewidywało dla każdej z płci odrębny zakres socjalizacji, edukacji oraz ról życiowych. Na poziomie ideału społecznego można było zaobserwować, z jednej strony, model ejszes chajel - kobiety dzielnej, strażniczki domowego ogniska, wspierającej męża w zdobywaniu wiedzy religijnej i przejmującej wszystkie praktyczne obowiązki: utrzymanie domu, wychowanie dzieci i zajmowanie się finansami ${ }^{25}$. Idealnym towarzyszem życia miał być dla niej mężczyzna uczony w Torze, dążący do uzyskania statusu mędrca talmudycznego (lamdena). W kontraście z krzepką, energiczną żoną był często przedstawiany jako wątty i delikatny ${ }^{26}$. Małżeństwo i posiadanie jak największej liczby potomków było z kolei najważniejszym wspólnym obowiązkiem pary. Ślady takiego spojrzenia na role poszczególnych płci można znaleźć w wielu tekstach. Wartą zacytowania jest piosenka ludowa zapamiętana z dzieciństwa przez Miriam Shomer-Zunser (notabene córkę Szomera):

On biegnie do synagogi

I studiuje wszystkie prawa

Biega tu i ówdzie

Warcząc jak niedźwiedź.

$* * *$

Ona spieszy się na targ

Kupić drewno, martwi się

O chleb do upieczenia

O podpałkę do rąbania;

O dzieci do oporządzenia

Po to ona tutaj jest,

Jedno położyć do łóżka,

Natrzeć główkę tamtemu;

Ukoić ból kolejnego

Do wychodka wziąć tamtego,

${ }^{25} \mathrm{Na}$ temat tego ideału zob. Moshe Rosman, The History of Jewish Women in Early Modern Poland: An Assessment, [w:] Jewish Women in Eastern Europe..., s. 38, a także Parush, Reading..., s. 39.

${ }^{26}$ Odnośnie do fizyczności żydowskich kobiet i mężczyzn w tamtym czasie zob. Shaul Stampfer, Families, Rabbis and Education: Traditional Jewish Society in Nineteenth-Century Eastern Europe, Oxford-Portland 2010, s. 32. 
Na dokładkę, jak co roku,

Trzeba powić następnego ${ }^{27}$.

Jak sugeruje utwór, kobieta poświęca się zgodnie z modelem ejszes chajel, natomiast „stworzony do wyższych celów” mężczyzna zajmuje się tylko studiowaniem Tory. Ideały te, choć nie pozostające bez wpływu na rzeczywistość, nie były jej dokładnym odbiciem. Wskazują na to badania historyczne, które zwracają uwagę na problem z tak silnie zarysowaną dychotomią, obejmującą wszystkie obszary życia (przypisując odpowiednio kobietom i mężczyznom poszczególne kategorie: jidysz-hebrajski i aramejski, sfera prywatna-sfera publiczna, targ-synagoga, tchines-Talmud, praktyczność-duchowość, świeckość-religijność) ${ }^{28}$. Ponieważ realia społeczno-ekonomiczne niewielu osobom pozwalały w pełni realizować ugruntowany ideał, istniały także inne możliwości kulturowej konstrukcji gender, co skutkowało przenikaniem się wspomnianych obszarów w ramach życia rodzinnego ${ }^{29}$. Pisze o tym na przykład Moshe Rosman:

Ekonomiczny wkład kobiety był równoległy do męskiego - i oba zazwyczaj się uzupełniały, trzeba było pracy obojga, aby zapewnić byt rodzinie; nie było tak, że to kobieta była przede wszystkim odpowiedzialna za fizyczną stronę życia, a mężczyzna za stronę duchową ${ }^{30}$.

Pomimo zinternalizowanego ideału genderowego poszczególni członkowie żydowskich rodzin nie dążyli do niego za wszelką cenę, a na praktykę dnia codziennego zawsze miały wpływ kwestie ekonomiczne. Jak podkreśla Yohanan Petrovsky-Shtern:

Rodzina żydowska była kształtowana przez ekonomię nie mniej niż przez religię. Żydzi poszukiwali partnerów i partnerek w zbliżonym wieku: handel wymagał równego udziału, wymiany doświadczeń oraz wspólnej odpowiedzialności [...]. Żydowska rodzina była komórką społeczną rządzoną przez duumwirat ${ }^{31}$.

Powyższe opisy odnoszą się przede wszystkim do społeczności sztetlowych z pierwszej połowy XIX w., a zatem do rzeczywistości, którą

${ }^{27}$ Cyt. za: Susan A. Glenn, Daughters of the Shtetl: Life and Labor in the Immigrant Generation, Ithaca-London 1990, s. 12. Podobną piosenkę cytuje w swojej pracy także Joanna Lisek. Zob. Lisek, Kol isze..., s. 137. Wszystkie tłumaczenia cytatów z jidysz i języka angielskiego pochodzą od autora artykułu.

${ }^{28}$ Parush Reading..., s. XVI-XVII.

${ }^{29}$ Weissler, Voices..., s. 50.

${ }^{30}$ Rosman, The History of Jewish Women..., s. 34.

31 Yohanan Petrovsky-Shtern, The Golden Age Shtetl: A New History of Jewish Life in East Europe, Princeton-Oxford 2014, s. 219. 
w późniejszym okresie kontestowała literatura haskalowa oraz następnie - literatura masowa. Pod koniec wieku ideał kobiety zarabiającej na dom był realizowany coraz rzadziej - już tylko 22 procent ankietowanych kobiet w wieku od 14 do 59 lat zajmowało się jakąkolwiek aktywnością ekonomiczną ${ }^{32}$. Podobnie w przypadku modelu uczonego w Torze i Talmudzie - z czasem coraz trudniej było znaleźć na rynku matrymonialnym rodzinę, która chciałaby utrzymywać uczącego się młodego małżonka ${ }^{33}$.

Trzeba jednak pamiętać, że współpraca przy utrzymywaniu gospodarstwa domowego łączyła się z odseparowaniem w innych dziedzinach życia. Przykładem takiej sfery była edukacja. Na życie chłopców w XIX w. nadal wpływał kulturowy ideał studiów nad Torą ${ }^{34}$. Bohater niniejszego artykułu, Nochem Meir Szajkewicz, tak opisywał genderowy podział ról w dziedzinie edukacji:

W tamtych dniach Hebrajczycy wierzyli, że celem życia każdego Żyda jest zanurzenie się w Torze i Talmudzie, a obowiązkiem każdej Żydówki jest utrzymywanie swojego męża i domu. Dlatego też porządni Żydzi trzymali swoich synów z daleka od naukowej wiedzy czy tajników handlu, aby mogli skupić się tylko na Talmudzie. Natomiast córki były uczone lokalnych języków oraz przedmiotów ścisłych na takim poziomie, aby mogły wystarczająco mądrze rozporządzać sprawami domu i handlu ${ }^{35}$.

Ciekawie koresponduje to ze wspomnianymi wyżej realiami ekonomicznymi, ale po raz kolejny widać, jak pewien ideał społeczny (wyrażony w cytacie) nie wytrzymywał zderzenia z rzeczywistością. Faktem jest jednak, że podczas edukacji swoich dzieci rodzice próbowali wyposażyć je w umiejętności dające szanse dalszego dążenia do niego. Choć większość mężczyzn ostatecznie odbierała jedynie podstawową edukację religijną w chederze, to ideał Żyda zaznajomionego z tekstami religijnymi był silnie ugruntowany.

Część analityczna tego artykułu będzie się opierać na próbie umiejscowienia twórczości literackiej Szomera w kontekście wyżej przedstawionych

${ }^{32}$ Hyman, Gender and Assimilation..., s. 68. Badaczka w innym tekście na ten temat uzupełnia tę informację hipotezą, że część aktywności ekonomicznych mogła nie zostać uwzględniona przez cenzus, por. Paula Hyman, Two Models of Modernization: Jewish Women in the German and the Russian Empires, [w:] Jews and Gender: The Challenge to Hierarchy, red. Jonathan Frankel, Oxford 2001, s. 45.

33 Rosman, The History of Jewish Women..., s. 38.

${ }^{34}$ Freeze, Hyman, Introduction...

${ }^{35}$ Cyt. za: Parush, Reading..., s. 40. Jak sugerują przytaczane tutaj prace historyczne, rzeczywistość charakteryzowała się dużo bardziej złożonymi postawami. Cytat ten jednak dobrze ilustruje pewien ideał, do którego starano się dążyć. 
ideałów, postaw i zmian, które miały wpływ na społeczność żydowską w Europie Wschodniej pod koniec XIX w. Czy i jak w opowieściach Szomera są opisywane ideały ejszes chajel i mędrca talmudycznego? Które z cytowanych ideałów są tam krytykowane, które prezentowane pozytywnie, a które konstruowane na nowo? Jak te utwory odnoszą się do kwestii oświecenia żydowskiego i pomysłów maskili na „modernizację” narodu? Czy Szomer, jako pisarz będący pod ideologicznym wpływem haskali36, całkowicie replikował wzorce z literatury haskalowej, czy wprowadzał również swoje własne, oparte na przykład na nowo powstających wówczas teoriach związanych z żydowskim gender? ${ }^{37} \mathrm{Czy}$ w jego twórczości można znaleźć echa przemian klasowych i ich wpływu na gender, takie jak mieszczańskie „feminizowanie kobiet”?

\section{Od „kramarki-kozaka” do anioła w domu}

Zakładając, że czytelniczka jego tekstów najczęściej była młodą osobą, Szomer starał się ideologicznie nakierować ją na odpowiednie według niego postawy i sposób myślenia mogące rzutować na wybory życiowe. Wśród portretowanych przezeń kobiet można zauważyć wyraźny podział na dwa główne typy. Pierwszym z nich są pozytywnie prezentowane młode dziewczyny realizujące nowe modele kobiecości i stawiane czytelniczkom za wzór do naśladowania (Mariete, Bluma, Ana Szpic, Dwojra Kalt). $\mathrm{Z}$ drugiej strony Szomer przedstawiał kobiety odrzucające rolę ,anioła w domu" (Perele, Frau Plefen), co za każdym razem jest krytykowane, i takie bohaterki najczęściej pojawiają się w roli czarnych charakterów.

Czarnym charakterem powieści Der katorżnik jest Perele, a jej negatywne cechy opisywane przez narratora przyćmiewają całkowicie postać jej męża Cemacha. Będąc służącą w domu Miriam (głównej bohaterki), wraz z małżonkiem obmyśla intrygę, na skutek której męża jej pracodawczyni zesłano na katorgę, a reszta rodziny traci cały majątek. Zostaje on przejęty przez Perele, która rozpoczyna nowe życie w innej, sztetlowej

${ }^{36}$ Wielu pisarzy szundowych, w tym Szomer, często czerpało z haskalowych koncepcji społecznych, ponieważ wychowywali się i rozpoczynali działalność w czasach rozwoju tego ruchu na ziemiach Imperium Rosyjskiego (aż do 1890 r.). Zob. Shulamit S. Magnus, Sins of Youth, Guilt of a Grandmother: M. L. Lilienblum, Pauline Wengeroff, and the Telling of Jewish Modernity in Eastern Europe, [w:] Jewish Women in Eastern Europe..., s. 90.

${ }^{37}$ Mam tu na myśli publikacje Freuda, Blühera czy syjonistyczną koncepcję „,nowego Żyda”. Wpływ każdej z nich na obraz Żyda-mężczyzny badał Daniel Boyarin. Zob. Boyarin, Unheroic Conduct..., s. 33-89, 189-220, 271-312. 
społeczności żydowskiej. Dzięki pieniądzom i stereotypowym cechom „Żydówki-kozaka”38 jej rodzina zajmuje bardzo wysoką pozycję w sztetlowej hierarchii. Wydają się oni zresztą idealnymi członkami lokalnej społeczności, a Perele jest tam znana z przewodzenia życiu duchowemu oraz z hojności, która była wartością tradycyjnie kojarzoną z mężczyznami:

Jego [Cemacha] żona Perele nie była gorsza od swojego wspaniałego męża, wszystkie kobiety odnosiły się do niej z szacunkiem. Pomimo że ciągle była zajęta swoimi sprawami, to nie wypuściła z rąk żadnej okazji na wypełnienie jakiejś micwy. Wszystkim biednym kobietom w połogu szykowała gotowane kury i wzmacniające zupki. Tańczyła na wszystkich weselach miejscowych sierot. Najokazalsze świece w synagodze na Jom Kipur należały właśnie do niej. Gabetes z babińca nie mogły się jej nachwalić. Chasie-Szprince, szameste, mówiła wiele razy: widziałam w swoim życiu wiele uczciwych kobiet, ale takiej szlachetnej osoby jak Perele nie spotkałam nigdy ${ }^{39}$.

Wszystko to jednak tylko pozory. Nikt nie wie, że Perele zatrudniła swoją dawną panią jako służącą i sadystycznie znęca się nad nią. $\mathrm{Na}$ początku powieści pojawia się scena, w której Perele w opryskliwy sposób każe Miriam sprzątać przed szabatem:

Ty kawale mięsa! - Wykrzyczała Perele na cały głos. - Widział kto, jak ona żyły sobie wypruwa przy pracy? Cały dzień i całą noc się leni, nie wie, co robić, a przecież powinna przygotowywać szabat. Wielka mi rzecz, przygotować szabat. Jakby ktoś usłyszał te narzekania, to by pomyślał, że chodzi o ucztę dla tysiąca gości. I ja mam ci mówić takie rzeczy? Myj mi te podłogi, ale to już! Dlaczego muszę cię jeszcze ganiać? Starczy mi już utrzymywania darmozjada w domu, to już lepiej zwyczajnie dawać komuś jeść. Miałabym chociaż micwę, gdybym cię po prostu karmiła ${ }^{40}$.

Perele jest silnie utożsamiana z religijnością. Narrator wielokrotnie wskazuje, że rytuały związane z judaizmem (szabat, swaty i śluby, cedaka) są dla niej niezwykle ważne, ale religijny system wartości nie powstrzymuje jej przed niemoralnym zachowaniem wobec innych. Ostatecznie zło w postaci Perele i Cemacha zostaje ukarane, gdy zostają aresztowani za podrabianie dokumentów.

Przeciwieństwem Perele w Katorżniku jest Miriam - wytrwale znosząca cierpienia i starająca się zachować resztki godności. Co ważne w przypadku

${ }^{38}$ Takim mianem (jid. a jidene a kozak) były określane w jidysz kobiety dominujące, energiczne. To określenie często miało wydźwięk pejoratywny, szczególnie w literaturze haskali i w szundzie. Zob. Parush, Reading..., s. 136.

${ }^{39}$ Szajkewicz, Der katorżnik..., s. 6.

40 Tamże, s. 7. 
tej postaci, wybawienie z cierpień przynosi jej dopiero mąż. Jej córka Rochl przedstawiona jest jako ta, która głośniej protestuje przeciwko sytuacji swojej rodziny. Obie jednak odzyskują dawne życie dopiero po przybyciu męża. Choć Rochl zobrazowana jest jako mniej pasywna, jej szansą na wyrwanie się z biedy, torpedowaną przez inne czarne charaktery, jest związek z bogatym mężczyzną. Inną pozytywną bohaterką tej powieści jest Mariete ${ }^{41}$, która rozkochuje w sobie Dowida, zaginionego syna Miriam, uczącego się w jesziwie. Nieśmiałemu chłopakowi podobają się w niej takie cechy, jak: piękno w „europejskim wydaniu”, wspaniały wokal (w tradycyjnych społecznościach głos śpiewającej kobiety jest uznawany za sferę tabu ${ }^{42}$ ), umiejętność grania na pianinie oraz inteligencja wynikająca z odebrania nowoczesnego wykształcenia. Mariete robi na Dowidzie tak piorunujące wrażenie, że zaczyna on kwestionować swoją tożsamość jako pobożnego Żyda. Ostatecznie po przypieczętowaniu związku porzuca studia w jesziwie i - jak można się domyślać - chce wieść z Mariete życie „zmodernizowanej, żydowskiej pary”.

W podobny sposób jak Mariete skonstruowana jest postać Blumy głównej bohaterki powieści Der blutiker adje. Choć akcja dzieje się jeszcze w czasie powstania listopadowego, Bluma jawi się jako kobieta, która już otrzymała wykształcenie w duchu haskalowym. Zna języki, pięknie śpiewa, gra na pianinie, a ponadto jest wrażliwa i wartościowa. W powieści zostaje przytoczony prasowy artykuł na jej cześć:

Małe miasteczko Najów ma szczęście, że mieszka w nim taki brylant, który pod słońcem zdarza się raz na kilkaset lat. Brylant, który swoim majestatycznym pięknem przyciagga wzrok każdego i który sprawia przyjemność każdemu sercu. To żydowska dziewczyna w wieku około 18 lat, aż ciężko uwierzyć, że człowiek może przybrać taką postać, która pasowałaby tylko do mieszkanek niebios. Wierzę, że jest to Wenus we własnej osobie ${ }^{43}$.

Warto zwrócić uwagę, że jej wykształcenie (bildung), skwitowane wcześniej w jednym zdaniu przez narratora, zajmuje nieproporcjonalnie mało miejsca w porównaniu z pojawiającymi się tam peanami na cześć jej piękna. Jest to silna, powtarzająca się tendencja u Szomera w opisywaniu młodych kobiet. Wszystkie pozytywne modele bohaterek są ,piękne” i jest

${ }^{41}$ Szomer, aby podkreślić status postaci, często posługiwał się imionami. Dlatego tradycyjne bohaterki otrzymywały takie imiona jak Perele, Grinele, Szprince, akulturowane kobiety zaś nosiły imiona brzmiące germańsko, jak na przykład Mariete.

${ }^{42}$ Zob. Lisek, Kol isze..., s. 20-21.

${ }_{43}$ Nochem Meir Szajkewicz (Szomer), Der blutiger adje, Wilne 1911, s. 6. 
to zawsze pierwsza z informacji, które na ich temat padają. Znamienne jest, że opis piękna zewnętrznego nie zawiera szczegółów, co jeszcze bardziej czyni z tych bohaterek bezosobowe manekiny, których rola sprowadza się do ozdoby domostwa umilającej gościom czas swoim śpiewem i grą na pianinie.

Podobnie jak Bluma opisana jest narzeczona bohatera powieści Halb mensz halb affe... - Ana Szpic. Pomimo stosunkowo ważnej roli dla akcji (narzeczona głównego bohatera, Izaaka Pintela) i pełnienia funkcji przeciwwagi dla czarnego charakteru niewiele można się dowiedzieć o tej postaci. Autor rzadko oddaje jej głos, opisując jej zachowania widziane ze swojej, męskiej perspektywy. Jej zalety sprawiające, że bohater tej historii zakochał się w niej, to piękno, wykształcenie (bildung, znów jednak rozumiane w zakresie znajomości języków obcych, manier i gry na pianinie), pochodzenie $\mathrm{z}$ „dobrego domu” oraz umiejętność prowadzenia miłej rozmowy. Tak opisywane jest ich pierwsze spotkanie:

Szczególnie silne wrażenie zrobiła na mnie panienka Szpic. Zobaczyłem w niej czyste, niewinne stworzenie, które można byłoby nazwać bożym aniołem; nie powiem, jak bosko piękna była, ale ze swoją piękną i czarującą twarzą mogłaby być typowana do najpiękniejszych na świecie, mówiła bardzo mało ${ }^{44}$, ale każde ze słów, które wypowiadała, było błyskotliwe ${ }^{45}$.

Pomimo że związek z tego typu panną dobrze się zapowiada, zaręczyny Izaaka z Aną zostają zerwane na skutek intrygi, a młoda narzeczona umiera ze zgryzoty. Delikatna konstrukcja psychiczna jest jedną z cech zmodernizowanych Żydówek u Szomera. Korzystając z ówczesnego dyskursu dotyczącego histerii jako wyłącznie kobiecej przypadłości, autor w ten sposób jeszcze bardziej „feminizuje” kobiety. Inną bohaterką doznającą groźnych dla zdrowia stanów psychicznych jest Ekaterina - żona głównego bohatera w opowieści Majn wajbs spazmes [Spazmy mojej żony] ${ }^{46}$. Chorobliwie zazdrosna kobieta na skutek komedii pomyłek (myśli, że jej mąż jest bigamistą) zaczyna mieć ataki spazmów. Rozedrgana psychicznie partnerka każdorazowo kontrastuje z racjonalnym, silnym bohaterem.

O wiele więcej miejsca i głosu otrzymuje w Halb mensz halb affe... czarny charakter - pani Plefen. Jest to przykład warty przytoczenia, ponieważ Szomer wprowadza tutaj nowy typ nieatrakcyjnej Żydówki. Jak słusznie

\footnotetext{
${ }^{44}$ Podkreślenie autora artykułu.

${ }^{45}$ Szajkewicz, Halb mensz halb affe..., s. 24.

${ }^{46}$ Nochem Meir Szajkewicz (Szomer), Majn wajbs spazmes, Wilne 1892.
} 
zauważył w swojej analizie Gennady Estraikh, Szomer krytykował nie tylko tradycyjne kramarki, ale również kobiety, które „wyemancypowały się za bardzo" ${ }^{47}$.

Frau Plefen to kosmopolitka posługująca się hebrajskim i próbująca (w XIX wieku!) rozwijać swoją karierę literacką. Podobnie jak wcześniej opisywane bohaterki odebrała edukację, jednak z perspektywy Szomera proces ten zaszedł w tym przypadku za daleko. Wejście na stereotypowo męski obszar zainteresowań naukowych (gemara, literatura, ambicje do uzyskania jak największego zakresu wiedzy świeckiej) oraz przyjęcie konwencjonalnych ról męskich (którymi według maskili była twórczość literacka, ale również samodzielna aktywność towarzyska) czynią z niej przeintelektualizowaną, odpychającą osobę, która całkowicie utraciła swoją kobiecość.

Obrazu dopełnia jej fizjonomia. Korzystając z dyskursów rasistowskich, narrator porównuje Plefen do orangutana:

Nazwa „urang-utang” (małpa) pasowałaby do niej lepiej niż miano kobiety. W całym moim życiu nie widziałem takiego brzydactwa. Wyobraźcie sobie osobę wysoką i szczupłą jak staromodny pogrzebacz, czarną jak Murzynka z szerokimi kocimi oczami. Nos (niech każdy żydowski dom będzie wolny od takich nosów), w którym przez każdą dziurkę mógłby przejechać wóz z czterema końmi ${ }^{48}$.

Przekraczanie granic genderowych i jego tragiczne skutki Szomer przedstawia na przykładzie intrygi pani Plefen, która postanowiła za wszelką cenę wyjść za bogatego wdowca Izaaka - głównego bohatera książki. Nie czekając na pierwsze oznaki zainteresowania, sama mu się oświadcza. Po odrzuceniu zalotów nie ustaje w staraniach. Choć nie jest opisywana jako osoba religijna, cynicznie posługuje się tradycyjnymi instytucjami żydowskimi, ponieważ jest świadoma, jaką władzę mają nad społeczeństwem. Z pomocą rabinów oraz przekupionej małomiasteczkowej społeczności próbuje zemścić się na bohaterze. Oskarża go, że po ślubie uciekł i zostawił ją samą w ciąży. Faktycznie oczekuje potomka (nie wiemy, kto jest ojcem, co sugeruje „niemoralne prowadzenie się”) i usiłuje zdjąć z niego groźbę bycia mamzerem (bękartem). Intryga w dużym stopniu się powodzi i pani Plefen mści się na swoim obiekcie uczuć.

${ }^{47}$ Szersze studium przypadku tej postaci przeprowadził w swoim artykule Gennady Estraikh. Zob. Estraikh, The Best-Selling Shomer...

${ }^{48}$ Szajkewicz, Halb mensz halb affe..., s. 6. 
W książkach Szomera można spotkać również pozytywnie nacechowany obraz emancypacji kobiet oraz pełnokrwiste bohaterki biorące sprawy w swoje ręce. Jednak nigdy nie przekracza to pewnej granicy, a ich aspiracje obejmują najczęściej małżeństwo z bogatym kawalerem. Przykładem takiej postaci jest Dwojra Kalt, główna bohaterka opowieści A sznel in noz. Podobnie jak inne młode dziewczyny jest przedstawiana jako piękna (szejn) i wykształcona (gebildet). Po przeżyciu zawodu miłosnego decyduje się na ślub z Żydem pochodzącym z tradycyjnej rodziny. Jej wyobrażenie siebie jako żony różni się jednak od koncepcji męża. Dwojra chce zajmować się domem i zarabiać, prowadząc działalność pożyczkową. Jej mąż, Todrus, ma jednak inne plany. Obsesyjnie skąpy i myślący tylko o pieniądzach, próbuje namówić ją do założenia sklepu, aby zarabiała tak, jak inne Żydówki ze sztetla. Z tej trudnej sytuacji bohaterka wyplątuje się samodzielnie, obmyślając podstęp prowadzący do uzyskania rozwodu i odzyskania posagu. Jako „nowoczesna kobieta” źle się bowiem czuje w swoim nowym domu, a ponadto przyświeca jej jeszcze inny cel: chce ułożyć sobie życie na nowo z zakochanym w niej (z wzajemnością) maklerem giełdowym. Jak widać w tej historii, również w przypadku sprawczości kobiet i ich działań emancypacyjnych Szomer wyraźnie zaznacza granicę: dziewczęta powinny się edukować tylko w ograniczonym zakresie, a spełnienie w roli kobiety możliwe jest jedynie przy mężu.

Podobny do powyższych wzorzec przygotowywania dziewcząt do życia był typowy również dla rodzin ze zdeklasowanej szlachty. Możliwe, że Szomer czerpał inspirację właśnie stamtąd. Jednak model ten nie jest zniuansowany w jego twórczości i nie budzi nawet cienia wątpliwości autora co do jego użyteczności społecznej i kwestii sytuacji ekonomicznej kobiet. A jest przecież oczywiste, że tego typu wykształcenie często uniemożliwiało im osiągnięcie samodzielności finansowej w przypadku rozwodu albo śmierci męża ${ }^{49}$. Brak zabezpieczenia finansowego w przypadku rozstania wymuszał na żonie większą uległość wobec małżonka, jednak taka perspektywa u Szomera się nie pojawia.

Ten model funkcjonował w realiach historycznych, kiedy dorastały już pierwsze pokolenia dziewcząt mające szansę na edukację świecką. Nawet od połowy XIX w. prywatne szkoły uczące podstawowych świeckich

${ }^{49}$ Przykładem krytyki takiego modelu jest powieść Elizy Orzeszkowej Marta, w której tytułowa bohaterka po śmierci męża nie jest w stanie utrzymać się z pracy, posiadając tylko podstawowe umiejętności szycia, gry na pianinie i konwersacji po francusku. Zob. Eliza Orzeszkowa, Marta, Warszawa 1885. 
przedmiotów przyjmowały w swoje progi także biedniejsze uczennice ${ }^{50}$. Tę grupę charakteryzowała duża chęć do edukacji - wyłączone do tej pory ze zdobywania wiedzy dziewczęta, pomimo wielu obowiązków domowych, często poświęcały swój wolny czas na udział w lekcjach i samodzielne dokształcanie się $e^{51}$. Młode Żydówki wyróżniały się wśród innych grup etnicznych i religijnych w Rosji stosunkowo wysokim uczestnictwem w edukacji na wyższych szczeblach, wliczając w to później również pierwsze słuchaczki na studiach wyższych. Wiele z nich wybierało następnie karierę nauczycielek ${ }^{52}$. System zdobywania wiedzy wśród dziewcząt również różnił się od tego znanego z chederów i jesziw. Dziewczęta w trakcie swojej edukacji napotykały dużo szerszy zakres zagadnień obejmujący zarówno treści świeckie, jak i tematy żydowskie ${ }^{53}$. Taki rodzaj edukacji korelował również z modelem spędzania wolnego czasu na czytaniu. Dziewczęta znacznie częściej sięgały po książki dla przyjemności, co miało później duże znaczenie dla dystrybucji literatury popularnej ${ }^{54}$. Jednocześnie w materiałach źródłowych pojawiają się pierwsze głosy krytyczne dotyczące kierunku rozwoju takiego modelu wykształcenia. Dotyczyły one przede wszystkim ukierunkowania edukacji dziewcząt na zostanie „damami salonowymi”, czyli na przykład - nauczania wyłącznie niemieckiego i francuskiego, gry na pianinie czy przywiązywania dużej wagi do ubioru. Jednak otwarcie nawet na takie zagadnienia sprawiało, że wzrastało upodobnienie się społeczeństwa żydowskiego do innych grup, a młode kobiety mogły odgrywać dużą rolę w procesach modernizacyjnych w społecznościach żydowskich.

Późnohaskalowa krytyka edukacji dziewcząt zwracała uwagę na okrojenie jej treści i na to, że rodziny zaczynają formatować swoje córki jako panny, które będą w przyszłości „,aniołami w domu” i dzięki bogatemu mężowi uzyskają awans społeczny ${ }^{55}$. Szomer jest w tym przypadku dużo bardziej sceptyczny w kwestii emancypacji kobiet. Choć często czynił z kobiet ważne bohaterki swoich książek, jednocześnie pozbawiał większość z nich nawet podstawowych cech fizycznych i osobowościowych. Nie widział problemu w kreowaniu kobiecego wzorca niemej i oddanej

${ }^{50}$ Eliyana R. Adler, In Her Hands: The Education of Jewish Girls in Tsarist Russia, Detroit 2010, s. 131.

51 Hyman, Gender and Assimilation..., s. 75.

52 Adler, In Her Hands..., s. 112-113.

53 Hyman, Gender and Assimilation..., s. 55.

${ }^{54}$ Parush, Reading..., s. 67.

55 Adler, In Her Hands..., s. 119. 
mężowi „damy salonowej”, w jego twórczości dominuje właśnie ten model pozytywnej młodej bohaterki.

Innym ważnym motywem w obrazowaniu postaci kobiecych przez Szomera jest wyraźna przepaść pokoleniowa. Kobiety starsze i w średnim wieku najczęściej opisywane są jako osoby budujące swoje życie na podstawie tradycji żydowskiej i starające się wypełniać zwyczajowy model Żydówki. Natomiast młodsze bohaterki są portretowane jako wyedukowane i zmodernizowane. Nawet jeśli pojawiają się wśród nich czarne charaktery, takie jak zawistne koleżanki, to nie są one już „zatrute” sztetlowym, tradycyjnym systemem wartości. Grinele, córka wspomnianej Perele, również jest portretowana negatywnie, jednak - w przeciwieństwie do swojej matki - nie jest pozornie religijną manipulantką, lecz nieokrzesaną, mało inteligentną dziewczyną. Biorąc pod uwagę to, że Szomer w mało subtelny sposób próbował kreować sympatie i antypatie czytelników i czytelniczek, można przyjąć, iż modelowa odbiorczyni tego tekstu miała być utwierdzana w następującym przekonaniu: bohaterki takie jak Bluma czy Mariete to ideały, do których warto się upodobnić. Postacie tradycyjnych Żydówek w świecie szundu sugerowały, że ten świat i system wartości odchodzą w niebyt. Natomiast kobiece postacie „wyemancypowane za bardzo", takie jak pani Plefen, pełniły funkcję ostrzeżenia przed wkraczaniem na obszary zarezerwowane dla mężczyzn.

\section{Od „jedwabnego Żyda” do businessmana}

Czytając opisy postaci kobiecych u Szomera, można zauważyć, że autor wielokrotnie prezentował mizoginiczny punkt widzenia. Pozytywnymi bohaterkami były zazwyczaj te kobiety, które niewiele mówiły i poddawały się autorytetowi mężczyzny. Nie oznacza to jednak, że silny krytycyzm autora był wymierzony jedynie w postawy kobiet. Szomer był równie krytyczny przy opisywaniu niektórych postaci męskich. Podstawowe rozgraniczenie wyglądało podobnie jak w przypadku modeli żeńskich. Autor wielokrotnie zestawiał ze sobą stary, sztetlowy ideał tradycyjnego ,jedwabnego Żyda” (należącego do elity intelektualnej, delikatnego, niepracującego fizycznie) z „nowym Żydem”, z męskością haskalowo sformatowaną na wzór zachodnioeuropejskich społeczeństw mieszczańskich.

Historia Gwald wu iz majn bord! jest jedną z wielu Szomerowskich fars opartych na tradycyjnych żydowskich swatach. O rękę Chanele, panny pochodzącej z bogatej, stosunkowo tradycyjnej rodziny, konkurują dwaj 
kandydaci: Todrus i Chaim. Pierwszy z nich to sztetlowy Żyd będący pod silnym wpływem swojej matki Drejzi. Pomimo dość zaawansowanego wieku (40 lat) nie ma stałego zajęcia, żyjąc zawsze na czyimś utrzymaniu. Poza wiedzą zdobytą w jesziwie nie posiada żadnych praktycznych zdolności, jest jednak zadowolony ze swojej pozycji społecznej, co podkreśla drogim tradycyjnym strojem i wypielęgnowaną brodą. Chociaż prezentowany jako nieudacznik, jest członkiem sztetlowej elity, ponieważ tego typu mężczyźni posiadają wiedzę i sprawują faktyczną władzę. W związku z wysoką pozycją społeczną przebiera w kandydatkach do założenia rodziny. Nie będąc zadowolony z poprzednich żon, dwukrotnie brał rozwód. Jednak tym razem jego życiowy schemat zawodzi. Przez własną naiwność i gnuśność ucieka mu szansa na pewny początkowo ślub oraz bezpieczeństwo ekonomiczne za sprawą posagu.

Jego rywal, Chaim, jest chłopakiem wyedukowanym również w dziedzinach świeckich, postacią spełniającą wszystkie wyznaczniki weltlechkajt (jid. 'świeckości'). Jego główną motywacją również nie jest miłość (Chanele podoba mu się fizycznie, jednak jako kawaler nie może nawet porozmawiać z niezamężną dziewczyną ze sztetla, a z powodu noszenia się po europejsku nie ma szans na akceptację jej ojca), lecz chęć wzbogacenia się za pomocą posagu, który w przypadku tej dziewczyny wynosi - w zależności od postępów w negocjacjach - od 5 tys. do 20 tys. rubli, co w tamtych czasach było bardzo wysoką kwotą. Aby uzyskać taką korzyść ekonomiczną, Chaim decyduje się na serię podstępów torpedujących starania matki Todrusa o doprowadzenie do szidechu. Próbuje sam się przedstawić ojcu Chanele jako uznany talent z najlepszej jesziwy, czyniąc jednocześnie starania o serce dziewczyny. Gdy wszystko to nie wystarcza, usiłuje udaremnić tnoim (spisanie kontraktu przedślubnego). Udaje mu się to, gdy podstępem doprowadza do zgolenia brody Todrusa i upokarza go w oczach społeczności. W tej historii występuje korelacja między uzyskaniem edukacji świeckiej a przejawianiem takich postaw życiowych, jak: samodzielność, spryt, aktywność życiowa. W porównaniu ze studentami jesziw i lamdenów, którzy od dzieciństwa są przygotowywani na swoją ścieżkę życiową i wspierani finansowo przez rodziny lub całe społeczności, zasymilowani bohaterowie według Szomera zasługują na dużo większy szacunek. Mają odwagę przekroczyć granice społeczne i klasowe, co nadaje ich życiu sens i poczucie sprawczości. Zgolenie brody Todrusa przez goja (rosyjskiego golibrodę) ma w tej powieści charakter symboliczny. Tak trywialny psikus potrafi obrócić wniwecz plany życiowe kandydata do ślubu. Męczyzna pozbawiony tego wyznacznika żydowskości ostatecznie zostaje z niczym. 
$\mathrm{Z}$ podobną parą mężczyzn porównywanych pod względem wartości matrymonialnej, a co za tym idzie - również i społecznej, mamy do czynienia we wspomnianej opowieści $A$ sznel in noz. Bohaterka, Dwojra Kalt, wychodzi za Hackela Pregla wywodzącego się z tradycyjnej rodziny. Nieprzemyślana decyzja sprawia, że jej życie staje się koszmarem. Wybranek nie spełnia bowiem oczekiwań, pomimo że wydawał się na początku „przystojnym, ładnym mężczyzną, całkiem wykształconym i modnie wystrojonym" ${ }^{56}$. Po bliższym poznaniu okazuje się jednak nienawistnym, skąpym człowiekiem próbującym wtłoczyć swoją żonę w ideał Żydówki-handlarki:

Zaczął dogadywać Dwojrze, że gotuje mięso na obiad, że utrzymuje służącą, że grzeje w samowarze. W końcu doszło do tego, że wyklinał ją za każdy grosz, który wydawali. [...] Nie mogła znieść też jego nawyków. Pomimo że bardzo lubił palić, to nigdy nie kupował tytoniu, zawsze prosił obcych, aby dali mu papierosa. Zwykł podnosić z ziemi ostatnie kawałki cygar, które ktoś już wyrzucił. O ubraniach nie było mowy, on sam sobie nie sprawiał nowych, a co dopiero Dwojrze. Nie mógł ścierpieć, kiedy Dwojra zakładała ładną sukienkę. „Dobre ubranie zakłada się na święto albo w gości” - krzyczał - „a tak to można brać, co jest”. Nie potrzebujesz więcej, niż ja uważam. A mnie się będziesz podobać, jak będziesz nosić proste ubrania $^{57}$.

Dwojra wyjeżdża do wielkiego miasta, rzekomo w celu nabycia towarów potrzebnych do założenia sklepu. Po kilku dniach bez wieści od niej Hackel zaczyna się denerwować, ale głównie dlatego, że żona zabrała ze sobą dużo gotówki. W przypadku tej pary Szomer posłużył się znaczącymi nazwiskami. Dwojra Kalt (kalt - jid. 'zimny') cierpliwie obmyśla plan uzyskania rozwodu i go realizuje, nigdy nie tracąc przy mężu rezonu. Pregel (jid. preglen - 'smażyć') ma wybuchowy charakter. Nie wiąże się to jednak z „męską stanowczością”, dlatego przesunięcie bohatera męskiego w kierunku cech kobiecych (nadmierna uczuciowość, a wręcz histeria) miało wywołać efekt komiczny, wyszydzający chłopaków z tradycyjnych domów jako stereotypowo niemęskich. Jak wcześniej wspomniałem, Dwojra chce uzyskać rozwód nie tylko po to, aby uwolnić się od Hackela i jego rodziny. Zakochana jest w Lazarze, $\mathrm{z}$ którym na skutek nieporozumienia zerwała dobrze rokującą znajomość. Mężczyzna ten jest opisywany jako całkowite przeciwieństwo Hackela:

\footnotetext{
56 Szajkewicz, A sznel in noz..., s. 5.

57 Tamże, s. 6-8.
} 
Lazar Perlberg był młodym człowiekiem, maklerem na giełdzie, odgrywał tam ważną rolę i zarabiał masę pieniędzy. Każdy darzył go poważaniem i sympatią. Zakochał się w Dwojrze nie na żarty i kręcił się koło niej tak długo, aż się w nim zakochała $^{58}$.

Oprócz tego, że Lazar posiada wszystkie cechy „nowego Żyda” (poważany zawód, szacunek również wśród gojów, zarobione własną pracą pieniądze pozwalające na prowadzenie mieszczańskiego życia), to on jest w tym związku osobą dominującą (w swoim małżeństwie Dwojra górowała w wielu kwestiach nad Hackelem i jest to prezentowane jako nienaturalne), co według sugestii autora wróży szczęśliwą relację opartą na autorytecie męża, któremu podlega siedząca w domu żona.

Dwójka bohaterów, których ważną częścią męskiej tożsamości jest ich stosunek do swoich żon, to Markus i Cemach z powieści Der katorżnik. Pierwszy z nich, bezpodstawnie oskarżony i zesłany na katorgę, poprzysięga zemstę, aktywnie dążąc do odzyskania swojego dawnego życia. Jego ambicją jest uratowanie swojej żony Miriam zdegradowanej do roli służącej. I faktycznie, dopiero jego powrót po kilkunastu latach jest wybawieniem dla żony i dzieci, co całkowicie realizuje model mężczyzny-wybawcy. Z kolei Cemach pozostaje pod silnym wpływem swojej żony Perele, co ostatecznie okazuje się jego zgubą. Pozwolenie kobiecie na wejście w obszar zarezerwowany (według narratora) dla mężczyzn ułatwia zdemaskowanie nielegalnych przedsięwzięć. $\mathrm{Z}$ tego porównania płynie wniosek, że korzyść może przynieść tylko określony podział ról, w którym to mężczyzna jest osobą dominującą, podejmującą ważne decyzje i wymierzającą sprawiedliwość.

Mężczyźni portretowani pozytywnie są zazwyczaj Żydami silnie akulturowanymi, odnoszącymi korzyści społeczne i ekonomiczne ze swojego awansu społecznego ${ }^{59}$. Główny bohater książki Halb mensz halb affe... przed poznaniem pani Plefen prowadzi dostatnie życie międzynarodowego handlarza. Nie przeznacza czasu na rozwój duchowy w ramach religii, wykorzystując go na doglądanie interesów - bez problemu porusza się po Europie, handluje z partnerami biznesowymi na tożsamych zasadach jako równoprawny członek mieszczańskiego społeczeństwa burżuazyjnego. Pomimo że jest wdowcem, nikt nie naciska na jego ponowny ożenek, co miałoby prawdopodobnie miejsce w tradycyjnej społeczności. Chce i jest

58 Tamże, s. 4.

${ }^{59}$ Szomer wyraźnie wskazuje w swoich książkach, że rozumie akulturację i modernizację pozytywnie - jako proces awansu społecznego. 
w stanie zapewnić swojej narzeczonej ubrania i biżuterię, widząc w niej przyszłą „ozdobę domu”, na którą będzie zarabiać. Dantes (Der blutiger adje) spełnia się jako artysta-śpiewak (nie jako kantor). Nie przejawia żadnych stereotypowo żydowskich cech widocznych na pierwszy rzut oka (jest modnie ubrany, mówi po włosku, nie ma pejsów ani brody), dlatego Bluma dopiero po jakimś czasie orientuje się, że jest Żydem. Również w miłości prezentuje zachowania romantycznego ideału znanego z literatur europejskich: pojedynkuje się o ukochaną, ratuje ją z opresji, ostatecznie oddaje życie w imię miłości; są to zachowania nieprzystające tradycyjnemu Żydowi, który według stereotypu kierowałby się zupełnie inną wizją związku.

Podobnie jak w przypadku portretowania postaci kobiecych ważnym kontekstem jest kontrast pokoleniowy. Posiadające cechy maskili pozytywne postaci męskie są zazwyczaj młode lub w sile wieku, co koresponduje z nieco już ugruntowanym wówczas obrazem maskila jako osoby młodej jo ${ }^{6}$. Z kolei elementem krytyki chłopców z jesziwy jest utożsamienie ich ze starszymi członkami ich rodzin, od których nie są wizualnie odróżniani. Posiadanie takich atrybutów jak broda, pejsy czy chałat upodabnia ich do ojców i dziadków, czyniąc ze wszystkich wyśmiewaną, starodawną zbiorowość sztetlowych Żydów.

Wydaje się, że to jeszcze za wcześnie ${ }^{61}$, aby duży wpływ na Szomera wywierały nurty myślowe, które również próbowały wyprowadzić koncepcję nowego Żyda, takie jak dzieła Freuda, Weininegera, Blühera czy syjonizm ${ }^{62}$. Można zatem przyjąć, że największy wpływ na obraz męskości kształtowany przez Szomera miały haskala i dyskursy modernizacyjne postulujące „produktywizację” tradycyjnego Żyda i wykształcenie nowego, który byłby głową rodziny i autorytetem dla żony. Podobnie jak w przypadku postaci kobiecych idealni mężczyźni również byli w jego powieściach opisywani według wzorców kształtującego się społeczeństwa mieszczańskiego. Gdyby nie ich imiona i podporządkowanie się do pewnego stopnia modelowi swatów żydowskich, można by odnieść wrażenie, że są to bohaterowie całkowicie akulturowani, nieróżniący się od innych członków burżuazyjnego mieszczaństwa.

${ }^{60}$ Shmuel Werses, Portrait of the Maskil as a Young Man, [w:] New Perspectives on the Haskalah, red. Shmuel Feiner, David Sorkin, London-Portland 2001, s. 128-143.

61 Analizowane książki pochodzą najpóźniej z lat dziewięćdziesiątych XIX w.

62 Zob. Boyarin, Unheroic Conduct..., s. 33-89, 189-220, 271-312. 


\section{Od swatów do miłości romantycznej}

Z poprzednich podrozdziałów o modelu kobiecości i męskości zarysowuje się już pewna wizja związków i małżeństwa w twórczości Szomera. Warto jednak uporządkować te elementy i zweryfikować, w jakim stopniu przyjmuje on postulaty maskili, a w jakim tworzy własny system opowiadania o miłości i rodzinie. Najbardziej wyrazistym postulatem zmiany społecznej w powieściach Szomera jest przesunięcie od tradycji żydowskich swatów w kierunku modelu miłości romantycznej znanego z literatur europejskich.

Tradycyjne, stereotypowo „sztetlowe” role społeczne podlegały silnej krytyce haskali, opierającej się m.in. na tendencji do przyjmowania zachodnich wzorców mieszczańskich, które stały w sprzeczności zarówno z wyżej wspomnianymi tradycyjnymi ideałami Żyda i Żydówki, jaki i z faktycznym podziałem ról w większości żydowskich rodzin.

Jednak nie oznaczało to zniesienia segregacji genderowej: tak jak w przypadku sztetlowych ideałów maskile przewidzieli dla każdej z płci odrębną rolę w społeczeństwie. Co do kobiet jako szkodliwy wskazywali ideał ejszes chajel i kramarki utrzymującej rodzinę. Według maskili zajmowanie się handlem nie przystawało kobietom, a tradycyjne Żydówki były uważane przez nich za główną przeszkodę na drodze do modernizacji narodu ${ }^{63}$. Nie oznacza to jednak, że maskile pozytywnie patrzyli na coraz powszechniejszą edukację dziewcząt. Nauka miała pozostać domeną mężczyzn, a kobiety powinny zostać „refeminizowane” w rolach matek, córek i strażniczek domowego ogniska. W tym przypadku również widać wyraźny wpływ pooświeceniowego mieszczaństwa, które dążyło do umieszczenia kobiet w domu, pomimo że w epoce wczesnonowożytnej były one jeszcze aktywne zawodowo zarówno w sztetlu, jak i w miastach Europy Zachodniej.

Jeśli chodzi o mężczyzn, to mieli upodobnić się genderowo do innych przedstawicieli tej płci w burżuazyjnych społeczeństwach europejskich. Oznaczało to zerwanie z tradycyjnym ideałem sztetlowego Żyda, którego autorytet i władza opierały się na zdobywaniu wiedzy. Postulowano podążanie w kierunku modelu mężczyzny zarabiającego na utrzymanie domu, przejawiającego inicjatywę i autorytet w sferze publicznej i prywatnej ${ }^{64}$.

${ }^{63}$ Parush, Reading..., s. 44.

${ }^{64} \mathrm{O}$ wyjątkowości genderowego ideału mężczyzny w społeczności żydowskiej i przemian na tym polu zob. Boyarin, Unheroic Conduct..., s. 31-80. 
Wizja takiej transformacji jako ideału pojawia się wielokrotnie w literaturze i publicystyce związanej z haskalą ${ }^{65}$.

Maskile krytykowali żydowskie tradycje związane ze swatami, które według nich przypominały negocjacje biznesowe. U podstaw tej krytyki leżała również odmienna od utrwalonej rola mężczyzny, którą ich zdaniem powinni przyjmować Żydzi. Tradycyjne żydowskie swaty opierały się na autorytecie i decyzjach ekonomicznych rodziców oraz silnym wpływie instytucji swata. Zgodnie z haskalową wizją męskości to sam kawaler powinien być głównym inicjatorem całego procesu. To podczas tej fazy relacji mężczyzna budował swój autorytet, który rozciągać się miał dalej, już na okres małżeństwa:

Maskile zaadaptowali model podziału genderowego obecnego w burżuazyjnym społeczeństwie europejskim i jego ideał nowoczesnego, uporządkowanego społeczeństwa, w którym oświecony i wyedukowany mężczyzna miałby niekwestionowany autorytet. Tego typu społeczeństwo miałoby, według nich, zastąpić tradycyjne role społeczne i naprawić szkody spowodowane odwróceniem ról genderowych. To wszystko miało wyleczyć żydowskie społeczeństwo z jego bolączek ${ }^{66}$.

Jak obecnie wiadomo, haskalowy projekt transformacji ludności żydowskiej nie odniósł pełnego sukcesu na terenach Europy Wschodniej, a zmiany potoczyły się inną trajektorią historyczną: tradycyjne instytucje sztetla nie upadły, ale został podkopany ich monopol w kształtowaniu postaw społecznych ${ }^{67}$. W badanym okresie wpływ haskalowego myślenia na tworzącą się nowoczesną literaturę jidysz był jednak stosunkowo duży, a również i część społeczeństwa - pod wpływem lektur i zmian cywilizacyjnych - mniej lub bardziej podążała ścieżką wyznaczoną przez dyskursy modernizacyjne. Dotyczyło to zarówno mężczyzn, jak i kobiet.

Krytyka tradycyjnych swatów u Szomera przybierała często postać dekonstrukcji rytuału za pomocą modelu farsy. Na tym założeniu opiera się akcja Gwald wu iz majn bord!, gdzie cały ceremoniał jest opisywany jako przestarzały teatr, w którym najmniej do powiedzenia mają potencjalni małżonkowie. To, że według Szomera instytucja tradycyjnego żydowskiego małżeństwa jest wydmuszką, widać przy próbach wyplątywania się bohatera Halb mensz halb affe... z małżeństwa z panią Plefen. Izaak decyduje się podporządkować instytucji sądu religijnego, aby jak najszybciej uwolnić się od pomówień. Bohaterowi wydaje się, że szybkie orzeczenie rabina,

${ }^{65}$ Parush, Reading..., s. 107.

${ }^{66}$ Tamże, s. 50.

${ }^{67}$ Shmuel Feiner, The Jewish Enlightenment, Philadelphia 2004, s. 365-373. 
choć oparte na innym systemie wartości, zdemaskuje intrygę pani Plefen. Jednak każdy z pytanych rabinów proponuje Izaakowi szybki rozwód, który przerwie kłopotliwe dochodzenie do prawdy, ukróci plotki i umożliwi mu kolejny ślub. Pintel, kierując się „męską dumą”, nie chce na to przystać. Postrzegając siebie jako honorowego mężczyznę, nie zamierza zgodzić się na rozwiązanie oparte na manipulacji faktami (nie było wszak żadnego ślubu). Duma i honor, wyraźnie prezentowane jako „męskie wartości”, z którymi utożsamia się Izaak, należą do elementów budowania nowego rodzaju męskości u Szomera. Z kolei kategoria prawdy i kłamstwa - tak ważna dla narratora - u rabinów i małomiasteczkowych Żydów schodzi na drugi plan w obliczu tradycyjnych praktyk społecznych.

W książkach $A$ sznel in noz oraz Der katorżnik model tradycyjnych swatów został zestawiony z modelem miłości romantycznej. W przypadku obu historii to właśnie związki oparte na tym drugim fundamencie zostają ostatecznie zawarte, a wszystkie starania rodzin i szadchenów nie przynoszą oczekiwanych skutków. Dowid, zaginiony syn Miriam (Der katorżnik), jest swatany z Grinele. Do pewnego momentu wydaje się, że dojdzie do ślubu, pomimo że młodzi są nim, a także sobą nawzajem, niezbyt zainteresowani. Pojawia się tutaj odbicie haskalowej krytyki małżeństw zawieranych w młodym wieku, kiedy narzeczeni nie są jeszcze gotowi do założenia rodziny. W przypadku Dowida doświadczeniem formującym go jako dorosłego mężczyznę jest pobyt u żydowskiego zarządcy majątku, ojca Mariete. Otwiera się tam na pozareligijny system wartości obejmujący również kwestię uczuć romantycznych. Z kolei Grinele do samego końca jest przedstawiana jako dziecinna i niedorosła jeszcze do poważnych spraw, takich jak zakładanie rodziny. Dopiero poznanie Mariete sprawia, że chłopak przekonuje się o tym, jak mogą wyglądać uczucia do osoby płci przeciwnej. Choć próbuje je powściągnąć, ostatecznie pisze list miłosny do panny i obiecuje wziąć ją za żonę. Tak ostatecznie się staje, a przemiana Dowida ze wstydliwego chłopca z jesziwy w mężczyznę walczącego o swoją damę doprowadza do szczęśliwego zakończenia. Dwojra (A sznel in noz) co prawda sama godzi się na wyjście za mąż za Hackela, jednak wszystko to się dzieje w ramach tradycyjnego rytuału i przy zaangażowaniu szadchenów. Ten związek szybko przechodzi kryzys i kończy się rozwodem. Natomiast jej relacja z Lazarem przetrwała wszystkie trudne chwile i akcja opowieści kończy się zawarciem przez nich ślubu. Wniosek z takich porównań jest dobrze widoczny: Szomer uważał związki zawarte w tradycyjny żydowski sposób za nieszczęśliwe, oparte 
na kalkulacji ekonomicznej, niedające spełnienia ani żonie, ani mężowi. Z kolei miłość romantyczna i więzi zadzierzgnięte poza sztywnym gorsetem społeczno-religijnych uwarunkowań sztetla dobrze rokują zdaniem Szomera. Mają duże szanse powodzenia, szczególnie jeśli dotyczy to bohaterów wyznających podobny (w domyśle: niesztetlowy, zmodernizowany) system wartości i preferujących podobną wizję małżeństwa.

Elementami budującymi model miłości romantycznej są detale, które nie mogłyby się pojawić w tradycyjnym żydowskim imaginarium. Jednym z nich są na przykład listy miłosne wymieniane między kochankami, często w sekrecie (Dowid pisze listy do Mariete, dzięki listowi Dwojra Kalt może odnowić kontakt z Lazarem, Miriam starymi listami od męża dodaje sobie otuchy w trudnych chwilach, ostatnie słowa Dantesa skierowane do Blumy mają formę zakrwawionego listu). Również bezpośrednia komunikacja twarzą w twarz może w tym modelu przebiegać bez kontroli rodziny. Kolejnym elementem jest odnoszący się do tradycji romantyzmu rozkwit uczuć w towarzystwie natury lub sztuki. Bluma pierwszy raz widzi Dantesa, gdy ten wykonuje arię operetkową. Dowid natomiast zakochuje się w Mariete, gdy dziewczyna śpiewa miłosne piosenki, akompaniując sobie na pianinie. Wiele motywów, takich jak pojedynkowanie się, jest również obecnych w romansach Szomera i innych autorów szundu. Następnym szundowym przykładem, w tym przypadku związanym z ucieczką dziewczyny w celu zawarcia ślubu, jest wątek zawarty w opowieści Reb Cedek Monisz, der far szikter in Sibir [Reb Cedek Monisz, zesłaniec na Syberię] ${ }^{68}$ Gerszoma Chaima Lewnera. Córka tytułowego bohatera ucieka z domu, aby zawrzeć małżeństwo z młodym kawalerem, który nie uzyskał akceptacji jej ojca z powodu silnego stopnia akulturacji. Co ważne, tego typu bunt nie wiąże się z ucieczką z gojem. Bluma z Der blutiger adje wielokrotnie odrzuca zaloty polskiego magnata, zaczyna poważnie interesować się Dantesem dopiero po odkryciu, że jest on Żydem. Dotychczasowa kwerenda wykazała, że kwestia asymilacji religijnej Żydówek poprzez małżeństwo z chrześcijaninem nie jest szeroko obecna w twórczości Szomera ${ }^{69}$.

$\mathrm{Z}$ drugiej strony, promowany model miłości romantycznej nie zrywał całkowicie z tradycyjnymi praktykami kulturowymi. Wiele fabuł romansowych swoją dynamikę nadal jednocześnie czerpie z formuły negocjacji przedślubnych, jak również z miłości romantycznej. Czasami właśnie na

${ }^{68}$ Gerszom Chaim Lewner, Reb Cedek Monisz, der far szikter in Sibir, Wilne 1898.

${ }^{69}$ Por. ChaeRan Freeze, When Chava Left Home: Gender, Conversion, and the Jewish Family in Tsarist Russia, [w:] Jewish Women in Eastern Europe..., s. 153-168. 
tradycyjnych swatach opiera się cała akcja. Szomer decydował się na uatrakcyjnienie fabuł informacjami o dużych posagach, często porzucając moralizatorski lub satyryczny ton. Możliwe, że ten rodzaj spojrzenia na swaty wynikał ze wspomnianej już próby uatrakcyjnienia przekazu dla modelowej czytelniczki, wciąż zazwyczaj zanurzonej w świecie tradycyjnego rynku matrymonialnego i negocjacji. Należy również pamiętać, że nie jest to pierwsze zapożyczenie i dostosowanie takiego modelu miłości. Dawna literatura jidysz to także romanse rycerskie i zaadaptowany model miłości romantycznej ${ }^{70}$. Szomer nie odwoływał się jednak doń bezpośrednio, uznając go prawdopodobnie za przestarzały i nieatrakcyjny. Skupiał się na dychotomii pomiędzy sztetlowymi praktykami związanymi ze swatami i małżeństwem oraz europejskim modelem miłości romantycznej.

\section{Podsumowanie}

Tak wyraźnie zarysowane koncepcje genderowe w porównaniu z ogromnym zasięgiem literatury szundu sprawiły, że czytelnicy i czytelniczki szeroko byli poddawani oddziaływaniu tych treści i odnosili je do otaczającego ich świata. Ze wstępnych badań na tym polu wynika, że czytelnictwo literatury popularnej miało wpływ na życiowe decyzje kobiet i dziewcząt oraz uczyniło z odbiorczyń szundu jeden z głównych motorów napędowych modernizacji społeczności żydowskiej. Przykładem takiej postawy może być historia Racheli Fajgenberg, którą przytacza w swoich wspomnieniach $^{71}$. Opisuje w niej swoją pierwszą „miłość”, którą wymyśliła sobie pod wpływem czytanej po nocach powieści Der katorżnik, wspominanej wielokrotnie w tym artykule. Dziewczyna wzbudziła wówczas niemałą sensację w sztetlu, ponieważ wybrankiem, z którym korespondowała, był noszący się po europejsku student medycyny. Jeżeli fantazja Racheli Fajgenberg na temat zmodernizowanego chłopaka była tak silna, że skutkowała mistyfikacją i fabrykowaniem listów pisanych przez rzekomego narzeczonego, to w przypadku innych odbiorczyń wyobraźnia mogła zmierzać w podobnym kierunku i rzutować na wszystkie trzy aspekty: obraz siebie jako potencjalnej partnerki, obraz wymarzonego narzeczonego oraz koncepcję wspólnego życia w związku. Nawet jeśli fantazja nie zawsze

${ }^{70}$ Zob. Bovo of Antona, [w:] Early Yiddish Epic, oprac. i thum. Jerold C. Frakes, Syracuse 2014, s. 238-316, oraz Briyo and Zimro, [w:] tamże, s. 419-430.

${ }^{71}$ Rachela Fajgenberg, Dziewczęce lata. Młodość w poleskim sztetlu, tłum. Inka Stempin, Warszawa 2021. 
wytrzymywała zderzenia z rzeczywistością, to zmiana preferencji odbiorczyń i odbiorców mogła w wielu przypadkach rzutować na wybory życiowe i przyspieszać kwestię zmian genderowych w społeczeństwie. Wydaje się jednak, że wpływ tych treści, szczególnie na młode czytelniczki, był dość znaczny, co nie byłoby zaskoczeniem w obliczu dotychczasowych badań nad kobiecym czytelnictwem ${ }^{72}$.

$\mathrm{Z}$ tego powodu zasadnym jest, aby poddawać rekonstrukcji ideologiczne inspiracje autorów jidyszowej literatury masowej. Tym bardziej że - na przekór stawianym mu zarzutom - Szomer jawi się jako twórca świadomy, który konsekwentnie umieszczał konstruowane przez siebie motywy w wielu powieściach. Przeprowadzona tu analiza wskazuje na to, że Szajkewicz w swoich utworach prezentował podejście do kwestii genderowych oparte w dużym stopniu na koncepcjach haskalowych. Należał do nich postulat „sfeminizowania kobiet” na modłę europejską i umieszczania ich w roli dobrych żon i córek. Pozytywne bohaterki spełniają haskalowy ideał pięknej narzeczonej lub żony podległej autorytetowi mężczyzny. Jeśli chodzi o mężczyzn, u Szomera również widać odbicie modernizacyjnych postulatów „produktywizacji” Żydów studiujących Torę i Talmud oraz próbę skonstruowania modelu „nowego Żyda” bliskiego koncepcji haskalowej: zmodernizowanego, odbierającego świecką edukację, utrzymującego rodzinę, posługującego się „europejskim systemem wartości” (pojawia się na przykład koncepcja honoru i męskiej dumy). Szomer podzielał haskalową krytykę swatów sprowadzającą je do transakcji zawieranych pod pieczą tradycyjnych instytucji. W to miejsce proponował model miłości romantycznej, zaistniałej bez tradycyjnych żydowskich pośredników.

Niektóre z elementów są jednak u Szomera wyjątkowe - głównie z powodu dostosowywania treści do modelowej czytelniczki. W porównaniu z literaturą haskalową liczba bohaterek jest większa i duża część z nich opisywana jest tak, aby młode dziewczęta mogły się z nimi utożsamić. Również zjawiska biedy czy cierpienia bohaterów i bohaterek były prawdopodobnie opisane po to, aby odwołać się do rzekomo typowo kobiecej emocjonalności i większej wrażliwości na krzywdy innych. Także instytucja swatów, pomimo że krytykowana, nie została całkowicie zatarta przez Szomera. Autor widział w niej szanse na uatrakcyjnienie akcji powieści, licząc na to, że farsa lub dramat oparte na czymś dobrze znanym z plotek i opowieści może wywołać w czytelniczce silne emocje,

${ }^{72}$ Zob. Ewa Kraskowska, Kobieta jako czytelnik. Czytelnik jako kobieta, [w:] taż, Czytelnik jako kobieta. Wokót literatury i teorii, Poznań 2007, s. 19-45. 
których będzie poszukiwać także w kolejnych książkach. Rozszerzeniem zasięgu oddziaływania swojej literatury w stronę tradycyjnego odbiorcy lub odbiorczyni były również przesunięcia związane z oceną wydarzeń i zachowania postaci, przejawiające się na przykład w wyborze bardziej tradycyjnie nastawionego narratora, co wprowadzało napięcie między poglądami autora i narratora ${ }^{73}$. W przypadku takich kwestii jak edukacja dziewcząt Szomer wydaje się natomiast dużo bardziej konserwatywny niż ówczesne dyskursy posthaskalowe, które wówczas już zaczęły krytycznie podchodzić do okrojonego programu skupiającego się na nauce manier, języków obcych i gry na pianinie.

Dlatego właśnie warto badać twórczość Szomera i innych autorów literatury popularnej również pod względem kolejnych zagadnień tam zawartych. Ten bogaty materiał źródłowy obejmuje również wiele innych treści będących jednocześnie odbiciem procesów historycznych zachodzących wówczas w społeczeństwie, jak i jednym z czynników kształtujących dynamikę zmian społecznych.

\section{Bibliografia}

\section{1. Źródła opublikowane}

Early Yiddish Epic, oprac i thum. Jerold C. Frakes, Syracuse 2014.

Fajgenberg Rachela, Dziewczęce lata. Młodość w poleskim sztetlu, tłum. Inka Stempin, Warszawa 2021.

Glikl: Memoirs 1691-1719, oprac. i wstęp Chava Turniansky, thum. Sara Friedman, Waltham 2019.

Lewner Gerszom Chaim, Reb Cedek Monisz, der far szikter in Sibir, Wilne 1898. Niger Szmuel, Di jidisze literatur un di lezerin (1913), [w:] tenże, Bleter geszichte fun der jidiszer literatur, Nju Jork 1959.

Orzeszkowa Eliza, Marta, Warszawa 1885.

Szajkewicz Nochem Meir (Szomer), A sznel in noz, Wilne 1896.

Szajkewicz Nochem Meir (Szomer), Der blutiger adje, Wilne 1911.

Szajkewicz Nochem Meir (Szomer), Der katorżnik, Wilne 1888.

Szajkewicz Nochem Meir (Szomer), Gwald wu iz majn bord! Eyn roman, Warsze 1930.

Szajkewicz Nochem Meir (Szomer), Halb mensz halb affe, oder, wu zucht men dem emes, Wilne 1888.

Szajkewicz Nochem Meir (Szomer), Majn wajbs spazmes, Wilne 1892.

Szulner Dora, Derinerungen wegn N. M. Szajkewicz (Szomer), [w:] taż, Gesztalten un derinerungen, Szikago 1956.

73 Więcej o tym zabiegu zob. Parush, Reading..., s. 151. 


\section{Opracowania}

Adler Eliyana R., In Her Hands: The Education of Jewish Girls in Tsarist Russia, Detroit 2010.

Boyarin Daniel, Unheroic Conduct: The Rise of Heterosexuality and the Invention of the Jewish Man, London 1997.

Estraikh Gennady, The Best-Selling Shomer and His Fear of Emancipated Women, [w:] Women, Men and Books: Issues of Gender in Yiddish Discourse, red. Gennady Estraikh, Mikhail Krutikov, Cambridge 2019.

Feiner Shmuel, The Jewish Enlightenment, Philadelphia 2004.

Glenn Susan A., Daughters of the Shtetl: Life and Labor in the Immigrant Generation, Ithaca-London 1990.

Hyman Paula, Gender and Assimilation in Modern Jewish History: The Roles and Representation of Women, Seattle-London 1995.

Hyman Paula, Two Models of Modernization: Jewish Women in the German and the Russian Empires, [w:] Jews and Gender: The Challenge to Hierarchy, red. Jonathan Frankel, Oxford 2001.

Jewish Women in Eastern Europe, red. ChaeRan Freeze, Paula Hyman, Antony Polonsky, Oxford-Portland 2005.

Kraskowska Ewa, Kobieta jako czytelnik. Czytelnik jako kobieta, [w:] taż, Czytelnik jako kobieta. Wokół literatury i teorii, Poznań 2007.

Lisek Joanna, Kol isze - głos kobiet w poezji jidysz (od XVI w. do 1939 r.), Sejny 2018.

Norich Anita, Jewish Literatures and Feminist Criticism: An Introduction to Gender and Text, [w:] Gender and Text in Modern Hebrew and Yiddish Literature, red. Naomi B. Sokoloff, Anne Lapidus Lerner, Anita Norich, New York 1992.

Parush Iris, Reading Jewish Women: Marginality and Modernization in NineteenthCentury Eastern European Jewish Society, tłum. Saadya Sternberg, Waltham 2004.

Petrovsky-Shtern Yohanan, The Golden Age Shtetl: A New History of Jewish Life in East Europe, Princeton-Oxford 2014.

Queer Theory and the Jewish Question, red. Daniel Boyarin, Daniel Itzkovitz, Ann Pellegrini, New York 2003.

Seidman Naomi, A Marriage Made in Heaven: The Sexual Politics of Hebrew and Yiddish, Berkeley 1997.

Shmeruk Chone, Le-toldot safrut ha-szund be-jidisz, „Tarbic” 52 (1983).

Stampfer Shaul, Families, Rabbis and Education: Traditional Jewish Society in Nineteenth-Century Eastern Europe, Oxford-Portland 2010.

Weissler Chava, Voices of the Matriarchs: Listening to the Prayers of Early Modern Jewish Women, Boston 1998.

Werses Shmuel, Portrait of the Maskil as a Young Man, [w:] New Perspectives on the Haskalah, red. Shmuel Feiner, David Sorkin, London-Portland 2001.

Adam Stepnowski Katedra Judaistyki im. Tadeusza Taubego

Uniwersytet Wrocławski adam.stepnowski@uwr.edu.pl 